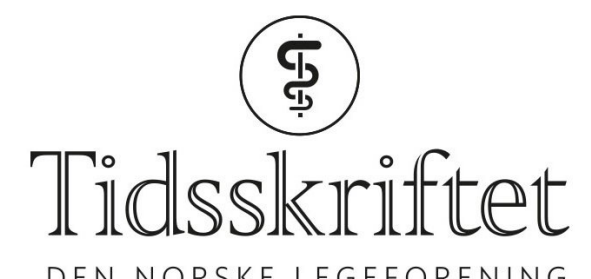

DEN NORSKE LEGEFORENING

\title{
Rettelse: Tilsetningsstoffer - er vi føre var?
}

RETTELSE

MARIT KOLBY ZINÖCKER

INGE ANDREAS LINDSETH

Tidsskr Nor Legeforen 2019; 139. doi: 10.4045/tidsskr.19.0474.

I Tidsskriftet nr. 12/2019 på s. 1127 skal det stå: En studie av monolaurin, en forbindelse som kan inngå ( $i$ ukjent mengdeforhold) i mono- og diglyserider av fettsyrer (E471), viste endring i tarmfloraen og førte til økt inflammasjon samt metabolsk syndrom hos mus (6).

Vi beklager feilen, den er rettet på nett.

Publisert: 17. februar 2020. Tidsskr Nor Legeforen. DOI: 10.4045/tidsskr.20.0104

(C) Tidsskrift for Den norske legeforening 2020. Lastet ned fra tidsskriftet.no 